INTERNATIONAL JOURNAL OF MULTIDISCIPLINARY RESEARCH AND ANALySis

ISSN[Online] : 2643-9875 || ISSN[Print] : 2643-9840

Volume 3 Issue 09 September 2020

DOI: 10.47191/ijmra/v3-i9-12, Impact Factor: 5.522

Page No : $134-137$

\title{
Open Educational Resources (OER): Benefits and Issues to Institutions, Educators and Learners in Islamic Studies
}

\author{
Ahmad Hisham bin Azizan \\ Academy of Contemporary Islamic Studies, Universiti Teknologi MARA (UiTM) Sarawak, Kampus Samarahan \\ 94300 Kota Samarahan, Malaysia
}

\begin{abstract}
Demand for quality education has been globally increased throughout the world. One of the methods to access quality education is via Open Educational Resources (OER). Open Educational Resources (OER) is not only a buzzing trend, but a realistic platform to realize the spirit of 'Education for All' and have gained increased attention for their potential and promise to eliminate demographic, economic, and geographic educational boundaries and to promote life-long learning and personalized learning. The sudden growth of Open Educational Resources (OER) provides new opportunities for education and learning at the same time, challenges established views about educating and learning practices in education. This study aims to explore an introduction to the emerging Open Educational Resources (OER) movement. At the same time, although learning resources are often considered as important intellectual property in a competitive higher education world, yet many critical issues have been identified that must be addressed, especially in Islamic studies. This study will determine the problems that we are facing today in education from technology to quality issues. A survey of the literature review was carried out to analyse the critical problems applied in Open Educational Resources (OER), especially in Islamic studies. A deep search of academic research and writing was performed includes books, journals, conference papers, articles, dissertations, and theses. This study also explains explicitly the benefits of open educational resources to the learners in their respective courses. The paper then clarifies certain challenges and issues hampering open education initiatives by highlighting the implications for institutions, teachers, and students.
\end{abstract}

\section{Keywords}

Open educational resources, benefits, issues, Islamic studies

\section{Introduction}

Demand for quality education has been globally increased throughout the world. One of the methods to access quality education is via Open Educational Resources (OER). Open Educational Resources (OER) is not only a buzzing trend, but a realistic platform to realize the spirit of 'Education for All' and have gained increased attention for their potential and promise to eliminate demographic, economic, and geographic educational boundaries and to promote life-long learning and personalized learning. The sudden growth of Open Educational Resources (OER) provides new opportunities for education and learning for all people throughout the world. Unfortunately, learning levels in many countries are highly unequal. The main reason is the restrictions on the use of resources. Although the word 'open' is to make education easier for those who need or wish for alternative opportunities to the traditional system, there are still many critical issues within Open Educational Resources (OER).

This article begins by discussing the benefits of Open Educational Resources (OER) in Islamic studies. Finally, this paper will summarise the issues hampering open education resources by highlighting the implications for institutions, teachers, and students especially, in Islamic Studies.

\section{Benefits of Open Educational Resources in Islamic Studies}

Open Educational Resources (OER) isn't only a buzzing trend but a sensible platform to appreciate the spirit of 'Education for All' and offers many benefits to institutions, educators, and learners. The advantages of OER that specialize in Islamic Studies are: 


\section{Open Educational Resources (OER): Benefits and Issues to Institutions, Educators and Learners in Islamic Studies}

\section{$2.1 \quad$ Free access}

OER comes with the concept of free. The terms free in this context mean without cost or no cost to access any resources to get the information you want in your study. In Islamic studies, providing free access to educational resources on a global scale have a great impact on educators, students, and self-learners to use and reuse for teaching, learning, and research. Educators can deliver the learning content, students can search and organize the content in which manner they want and selflearners can learn new knowledge about Islam. Islam is so simple which people can teach, search, and learn by any method which indicated the usefulness of Open Educational Resources (OER) in Islamic Studies(Belawati, 2014).

\subsection{Contribution to the community}

The increasing demand for education is happening throughout the world(Jiayin, 2020; Godwin-Jones, 2014). Open learning has the advantage of both informal learning and formal learning. The flexibilities of online open learning and resources are important keys for learners because if there is no time constraint for them to join and learn, they will surely enjoy the classes. Learners engaged in open learning are in different age groups and from various cultural backgrounds. It means everyone can learn from anywhere or everywhere as long as you have a desire to improve yourself in education. It's massive opportunities for disadvantaged learners for whom the accessibility of resources was previously unavailable.

\subsection{Encourages teaching innovation}

Nowadays, OER is known as a special type of innovation (Dominic et.al., 2015; Salmon, 2016). OER can lead to a full redefinition of the teaching and learning environment to improve education and enhance the teaching and learning process. One of the innovations is MOOC (Massive Open Online Course). MOOCs have developed into a significant talking point for universities and education reformers. What makes MOOCs so hype nowadays? In MOOCs, no prerequisite course and no formal accreditation means anyone can participate online. For example, in Islamic studies, educators structure the learning resources, lectures, and activities of learners. As a result, learning is directed toward the objectives and outcome of the courses.

\subsection{Save time and efforts}

Nowadays, due to the current information and technology revolution, which has affected all aspects of human life, such as education, communication, and work, the possibility to attain knowledge quiet easily. It's different in the early eighties or nineties, where some people had to travel far either by walking or using a bicycle to libraries and bookshops to be able to copy an article or the cover page of a recent book. Less time and energy-consuming makes us wonder why some people still lazy to fill their life with knowledge. It's all about attitude.

Open education has come with non-traditional ways of learning. Furthermore, OER has linked informal and formal education by using different resources. OER allows teachers and learners to access learning materials with permission to edit and modify the content to meet their needs and expectations. Besides, open education is cost-effective since it is not necessary to print textbooks, and that it promotes informal learning by not requiring credentials. Judith and Bull (2016) have stressed the importance of open education's enhancing the quality of learning by allowing more participants to be involved in it, which results in a more personalized and efficient learning process (Berti, 2018).

\subsection{Lowers costs for learners}

The cost of materials such as textbooks has increased dramatically in the past few decades. These disadvantageous sometimes cause the students to make silly decisions in their educational goals, such as enrolling in fewer courses per semester (Diener, Diener, \& Biswas-Diener, 2017). In response to these issues, Open Educational Resources (OER) have been developed. It's so helpful because not all learners have the financial backing to further their education. Free access resources are the only solution to continue their study without ever withdrawing it. Course withdrawals are expensive to both the student and the institution. Although students withdraw from classes for many reasons, such as dislike of the instructor or lecturer, a common reason for withdrawing from a course is financial problems. It's a common reason anywhere and everywhere in the world so to avoid it, open educational resources have been created to help the learners in their education.

\section{Issues regarding Open Educational Resources in Islamic Studies}

On the other hand, there are some issues related to Open Educational Resources (OER), especially in Islamic studies.

\subsection{Perception of Quality}

One of the major concerns of Open Educational Resources (OER) is quality. Finding the information may not be too difficult but some people might have a harder time judging whether or not to use it. The priority when using Open Educational Resources (OER) is to identify high-quality content. It is difficult to define what 'quality' means in the context of Open Educational Resources (OER). Content quality is perhaps the most intriguing aspect of OER quality. The accuracy and applicability of the content within Open Educational Resources (OER), however, presented several problems (Camilleri et.al.,2014). Questions that always been asked to ourselves when assessing the accuracy include, who wrote it? Do they have expertise in this field? 


\section{Open Educational Resources (OER): Benefits and Issues to Institutions, Educators and Learners in Islamic Studies}

Does it contain any mistakes? Unfortunately, these questions were often left unanswered. Wikipedia is an obvious example where much of their content is being developed by individuals in their spare time. Their content "may contain errors". How much does one rely on content that comes with a warning that it may be incorrect? Whether the material is free or expensive, quality does matter.

\subsection{Time consuming and commitment issue}

Searching for existing Open Educational Resources (OER) can be extremely time-consuming. It's not an easy task to plan an online lecture compared with traditional hour-long lectures. For online lectures, a platform to use, update teaching materials, student consultation, and assessment takes more time to prepare. For example, during this pandemic, some lecture maybe has this problem. Not everyone expert with online teaching and learning.

For students or self-learners, finding the accurate Open Educational Resources (OER) can be extremely hard and difficult. Some students or learners will take more time and some will take less time to find pieces of course information depend on their commitment. It's hard work versus a lazy attitude. So, time consuming and commitment attitude can be crucial to make Open Educational Resources (OER) successful in the future.

\subsection{No encouragement or reward}

Another noticeable barrier of Open Educational Resources (OER) is the lack of reward to encourage staff members to produce open content (Olena, Susan, 2019) and a lack of skill to do so. With no institutional or peer recognition or encouragement, there is little incentive for faculty members to take on the extra burden of developing and refining Open Educational Resources (OER) content. Although some staff members maybe do it sincerely, therefore to encourage staff members, there must be an adequate reward and recognition. Awards, publicizing the resulting works, encouraging staff members to present, and supporting their travel to educational events are necessary to make the staff member feel appreciated for what they have done in their institution.

\subsection{Technology concerns}

A variety of technical issues also have an impact on Open Educational Resources (OER). The major problem is the use of internet service and computer hardware available to learners. It's a common problem, especially inrural areas. Computers, laptops, and smartphones may not be a problem but the main problem is data. Limited internet data make Open Educational Resources (OER) very limited, in other words very limited teaching and learning progress.

\subsection{Intellectual property/copyright concern}

One of the foremost headaches in Open Educational Resources could be a copyright concern. Material possession issues are at the centre of OER. It was suggested that the problem of copyright and ownership of the fabric is "the root reason behind slow development during this field," inhibiting educators or lecturers to form their teaching content available to the net community.

The term 'open' is to make the contents available to the public at no cost. Despite that, not all the content can be open or read at one time. Sometimes people must sign up or pay to access all the content on the web page. That's referred to the intellectual property. All know every country around the world has different laws and implications concerning intellectual property. Before publishing educational resources that make use of third-party materials on the net, the author, or the publisher must ensure they have the right to use these materials.

\section{Conclusion}

Open Educational Resources offer the potential to transform and enhance distance education. The long-term key to their usefulness will, however, be determined by the ability to access and use what has been stored to create high-quality online courses able to meet the needs of diverse learners.

\section{References}

1) Belawati, T. I. A. N. (2014). Open education, open education resources, and massive open online courses. International Journal of Continuing Education and Lifelong Learning, 7(1), 2-15. Retrieved from

https://oerknowledgecloud.org/sites/oerknowledgecloud.org/files/tian02eng.pdf.

2) Berti, M. (2018). Open educational resources in higher education. Issues and Trends in Educational Technology, 6(1),1-9.

3) Butcher, N. (2015). A basic guide to open educational resources (OER). Commonwealth of Learning, Vancouver and UNESCO. Retrieved from http://oasis.col.org/handle/11599/36 


\section{Open Educational Resources (OER): Benefits and Issues to Institutions, Educators and Learners in Islamic Studies}

4) Camilleri, Anthony F.; Ehlers, Ulf Daniel; Pawlowski, Jan. (2014). State of the Art Review of Quality Issues related to Open Educational Resources (OER). Luxembourg: Publications Office of the European Union 2014, 52 S. - (JRC Scientific and Policy Reports).

5) Cape Town Open Education Declaration. (2008). Read the declaration Retrieved June 28, 2020, from www.capetowndeclaration.org/read-the-declaration.

6) Diener, E., Diener, C., Biswas-Diener, R. (2017) Open-source for educational materials making textbooks cheaper and better. In: Jhangiani, R. S., Biswas-Diener, R. (eds) Open: The philosophy and practices that are revolutionizing education and science, London, UK: Ubiquity Press, pp. 209-217.

7) Godwin-Jones, R. (2014). Global reach and local practice: The promise of MOOCs. Language Learning \& Technology, 18(3), 5-15. Retrieved from http://It.msu.edu/issues/october2014/emerging.pdf

8) Hylen, Jan. (2006). Open educational resources: Opportunities and challenges in Proceedings of Open Education. Paris, France. OECD's Centre for Educational Research and Innovation.

9) Jiayin Lin, Geng Sun, Jun Shen. (2020). ADAPTIVE MICRO LEARNING: Using Fragmented Time to Learn. World Scientific.

10) Judith, K., \& Bull, D. (2016). Assessing the potential for openness: A framework for examining course-level OER implementation in higher education. Education policy analysis archives, 24, 42.

11) Kurt, S. (2017). "Open and Free Educational Resources (OER) For Teaching \& Learning," in Educational Technology, July 1, 2020. Retrieved from https://educationaltechnology.net/open-free-educational-resources-oer-teachinglearning/

12) Olena Zhadko\& Susan Ko. (2019). Best Practices in Designing Courses with Open Educational Resources. Routledge.

13) Orr Dominic, Rimini Michele, van Damme Dirk. (2015). Educational Research and Innovation Open Educational Resources A Catalyst for Innovation: A Catalyst for Innovation. OECD Publishing.

14) Salmon, Gilly. (2005). Flying not flapping: a strategic framework for e-learning and pedagogical innovation in higher education institutions in Journal Research in Learning Technology, Volume 13, 2005 - Issue 3. 